Available online at: http://journal.unj.ac.id

Jurnal

Pensil

Pendidikan Teknik Sipil

Journal homepage: http://journal.unj.ac.id/unj/index.php/ipensil/index

\title{
PENGEMBANGAN E-MODULE PRAKTIK BATU BETON DI PROGRAM STUDI PENDIDIKAN TEKNIK BANGUNAN UNJ
}

\section{DEVELOPMENT OF CONCRETE STONE PRACTICE E-MODULE IN THE BUILDING ENGINEERING EDUCATION STUDY PROGRAM UNJ}

\author{
Mohamad Rizki Indra', Rosmawita Saleh², Tuti Iriani ${ }^{3}$ \\ 1,2,3 Universitas Negeri Jakarta, Jl. Rawamangun Muka Raya No. 11, DKI Jakarta, 13220, \\ Indonesia \\ 1mohamadrizkiindra 5415161274@,mhs.unj.ac.id, 2rosmawitasaleh@unj.ac.id, \\ 3t iriani@yahoo.com
}

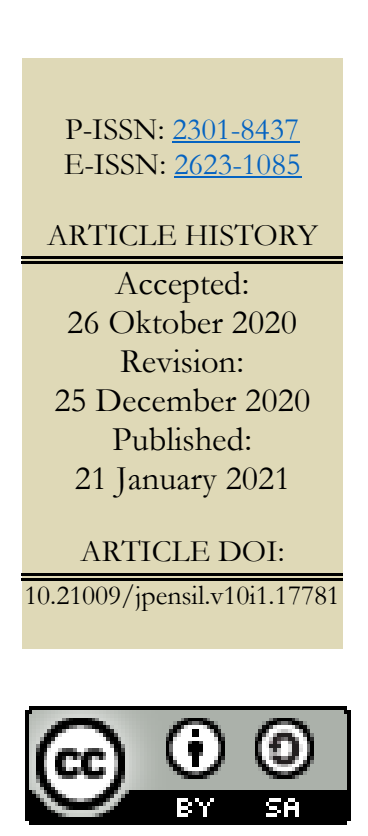

Jurnal Pensil : Pendidikan Teknik Sipil is licensed under a Creative Commons Attribution-ShareAlike 4.0 International License (CC BY-SA 4.0).
Abstrak

Penelitian ini merupakan penelitian pengembangan bahan ajar modul elektronik pada perkuliahan Praktik Batu Beton di Pendidikan Teknik Bangunan Fakultas Teknik Universitas Negeri Jakarta. Metode yang digunakan dalam penelitian ini adalah Research and Development (R广D) ADDIE yang terdiri dari analisis pengembangan desain, implementasi dan evaluasi. Penelitian ini dimulai dengan pengumpulan data analisis kebutuhan, validasi produk dan uji coba terbatas pada pengguna pengembangan bahan ajar. Hasil uji kelayakan ahli materi pada modul elektronik dinyatakan sangat layak dengan persentase kelayakan sebesar $88 \%$ dan hasil yang diberikan ahli media dinyatakan sangat layak dengan persentase sebesar $81,5 \%$. Sedangkan hasil penilaian yang diberikan penggunan modul elektronik menyatakan persentase sebesar $86 \%$ dengan kategori sangat baik. Berdasarkan kelayakan dan uji coba terbatas, dapat disimpulkan bahwa modul elektronik pada mata kuliah Praktik Batu Beton dapat digunakan dalam pembelajaran perkuliahan Praktik Batu Beton di Pendidikan Teknik Bangunan Fakultas Teknik Universitas Negeri Jakarta.

Kata kunci: bahan ajar, modul elektronik, praktik batu beton

Abstract
This study attempt to develop teaching materials in electronic module in lecture
Practices Concrete Education Study Stone in the Building Technique of Engineering
Faculty, Jakarta State University. Methods used in this research was Research and
Development (RnD) of ADDIE was consisting from the Analysis, Development,
Design, Implementation, and Evalution. This study started by gathering dat over
needs analysis, the validation by the products and limited to the trial of the users
know developed. The results of the feasibility of guven validator material opposition
to electronic modules stated very worthy of the percentage of $88 \%$ feasibility and the
result give by validator media against electronic modules stated very worthy of the
percentage of $81,5 \%$. While, the assessment results of the given users to electronic


module said $86 \%$ to a category very good. Based on the appropriateness and limited trial, it can be concluded that module electronic lecture Practice Concrete can be used in learning lecture Practices Blocks of Concrete in the Building Technique of Engineering Faculty, Jakarta State University.

Keywords: teaching materials, electronic module, practices concrete stone

\section{Pendahuluan}

Perkembangan era revolusi industri 4.0 memberikan perubahan yang berpengaruh besar dalam kehidupan manusia. Perubahan yang sangat dirasakan adalah berkembang dengan pesatnya aspek teknologi, informasi dan komunikasi. Salah satu dampak dari perkembangan teknologi adalah kemajuan di bidang pendidikan. Perkembangan teknologi selalu beriringan dengan perkembangan dalam dunia pendidikan. Berkembangnya teknologi di dunia pendidikan memberikan dampak positif dalam proses belajar mengajar. Sehingga, hal ini menuntut pendidik untuk memperbaharui sistem pembelajaran dengan memanfaatkan teknologi terkini. Upaya yang dapat dilakukan oleh pendidik adalah memanfaatkan teknologi terkini untuk diterapkan ke dalam proses pembelajaran.

Menurut

Suwardana

(2018)

pendidikan diharapkan mampu memanfaatkan teknologi dalam upaya pengembangan bahan ajar menjadi lebih inovatif dan menarik guna meningkatkan minat dan memudahkan peserta untuk belajar. Selain itu, pendapat lain dikemukakan oleh Asmi (2018) bahan ajar yang inovatif pada dasarnya dapat diciptakan oleh dosen dengan memanfaatkan teknologi informasi yang menarik.

Pemanfaatan teknologi di dunia pendidikan dapat diterapkan dalam proses pembelajaran, seperti penerapan bahan ajar dalam bentuk digital. Pengembangan bahan ajar diperlukan untuk meningkatkan minat dan mempermudah peserta didik dalam melakukan pembelajaran. Pengembangan bahan ajar sebaiknya dilakukan berdasarkan kebutuhan peserta didik terhadap proses pembelajaran. Oleh karena itu, langkah awal dalam melakukan pengembangan diperlukan pengamatan dan penyebaran kuesioner analisa kebutuhan kepada peserta didik.

Praktik Batu Beton merupakan salah satu mata kuliah yang terdapat di program studi Pendidikan Teknik Bangunan FT UNJ yang mempelajari alat dan bahan, prosedur kesehatan dan keselamatan kerja (K3), langkah-langkah dalam pemasangan dinding batu bata, pemasangan keramik lantai dan dinding, serta pembuatan tulangan struktur. Berkaitan dengan mata kuliah Praktik Batu Beton, sebelumnya terdapat penelitian yang dilakukan oleh Rizka Ayu Romana pada tahun 2019 terkait Pengembangan Jobsheet Praktik Batu Beton Sesuai dengan Standar Kompetensi Kerja Nasional Indonesia (SKKNI).

Berdasarkan penyebaran kuesioner analisa kebutuhan kepada mahasiswa program studi Pendidikan Teknik Bangunan FT UNJ, terdapat total responden sebanyak 45 mahassiwa yang terdiri dari 21 mahasiswa angkatan 2016, 14 mahasiswa angkatn 2017, dan 10 mahasiswa angkatan 2018. Hasil analisa kebutuhan menunjukan bahwa bahan ajar yang cocok digunakan dalam mata kuliah Praktik Batu Beton, sebanyak $80 \%$ menjawab modul elektronik, $11.2 \%$ menjawab Jobsheet, $4.4 \%$ menjawab modul cetak, dan 4,4\% menjawab buku elektronik. Analisis lebih lanjut, sebanyak 97.5\% mahasiswa menjawab setuju jika modul elektronik dijadikan sebagai bahan ajar dalam mata kuliah Praktik Batu Beton. 
Salah satu bahan ajar yang dapat dikembangkan adalah modul. Menurut Prastowo (2015) modul adalah sebuah bahan ajar yang disusun secara sistematis dengan bahasa yang mudah dipahami oleh peserta didik sesuai tingkat pengetahuan dan usia mereka. Sehubungan dengan pemanfaatan teknologi, modul dapat dikembangkan menjadi modul elektronik atau e-modul. Menurut Prasetiyowati \& Tandoyonomanu (2015) modul elektronik adalah bahan ajar mandiri yang disusun secara sistematis ke dalam pembelajaran terkecil untuk mencapai tujuan pembelajaran tertentu yang disajikan dengan bentuk elektronik yang bersifat Self Instruction, Self Contained, Stand Alone, Adaptif, dan User Friendly yang memuat satu materi pembelajaran. Sedangkan menurut Purwaningtyas (2017) modul elektronik merupakan bentuk bahan ajar yang sesuai dengan karakteristik materi ajar yang telah dikemas dalam satu kesatuan utuh yang disusun secara sistematis, dipelajari secara mandiri dan lebih aktif oleh pembelajar sesuai dengan kecepatan atau kemampuannya tanpa bimbingan dari guru.

Penelitian ini bertujuan untuk mengembangkan bahan ajar mata kuliah Praktik Batu Beton berupa modul elektronik atau $e$-modul. Selain itu, $e$-modul ini diharapkan dapat memudahkan peserta didik dalam melakukan pembelajaran, serta dapat meningkatkan minat dan hasil belajar peserta didik.

\section{Metode Penelitian}

Penelitian ini dilaksanakan pada bulan Maret sampai dengan bulan Agustus 2020, di Program Studi Pendidikan Teknik Bangunan Fakultas Teknik Universitas Negeri Jakarta. Metode yang digunakan dalam penelitian ini adalah penelitian riset dan pengembangan (Research and Development), sedangkan model yang dipilih adalah model ADDIE (Analysis, Design, Development, Implementation and Evaluation). Alasan penggunaan model ADDIE dalam penelitian ini, karena memiliki prosedur tahapan yang sistematik dalam setiap langkahnya dan selalu mengacu pada tahap sebelumnya. Sehingga dengan menggunakan model ini, diharapkan menghasilkan produk yang efektif. Tujuan dari penelitian ini adalah mengembangkan bahan ajar berupa modul elektronik atau $e$-modul pada mata kuliah Praktik Batu Beton dan sasaran dari pengembangan e-module ini adalah mahasiswa yang akan mengampu mata kuliah Praktik Batu Beton di Program Studi Pendidikan Teknik Bangunan FT UNJ.

Pengumpulan data yang dilakukan dalam penelitian ini menggunakan instrumen non tes, yaitu menyebarkan angket kuesioner untuk mengetahui nilai kelayakan, penilaian pengguna serta efektifitas dari modul elektronik Praktik Batu Beton yang dikembangkan. Penilaian kelayakan modul dilakukan oleh ahli materi dan ahli media. Sedangkan, uji efektifitas dilakukan melalui uji coba terbatas dengan memberikan soal pre-test dan post-test kepada 20 mahasiswa yang telah mengampu mata kuliah Praktik Batu Beton di Program Studi Pendidikan Teknik Bangunan FT UNJ. 


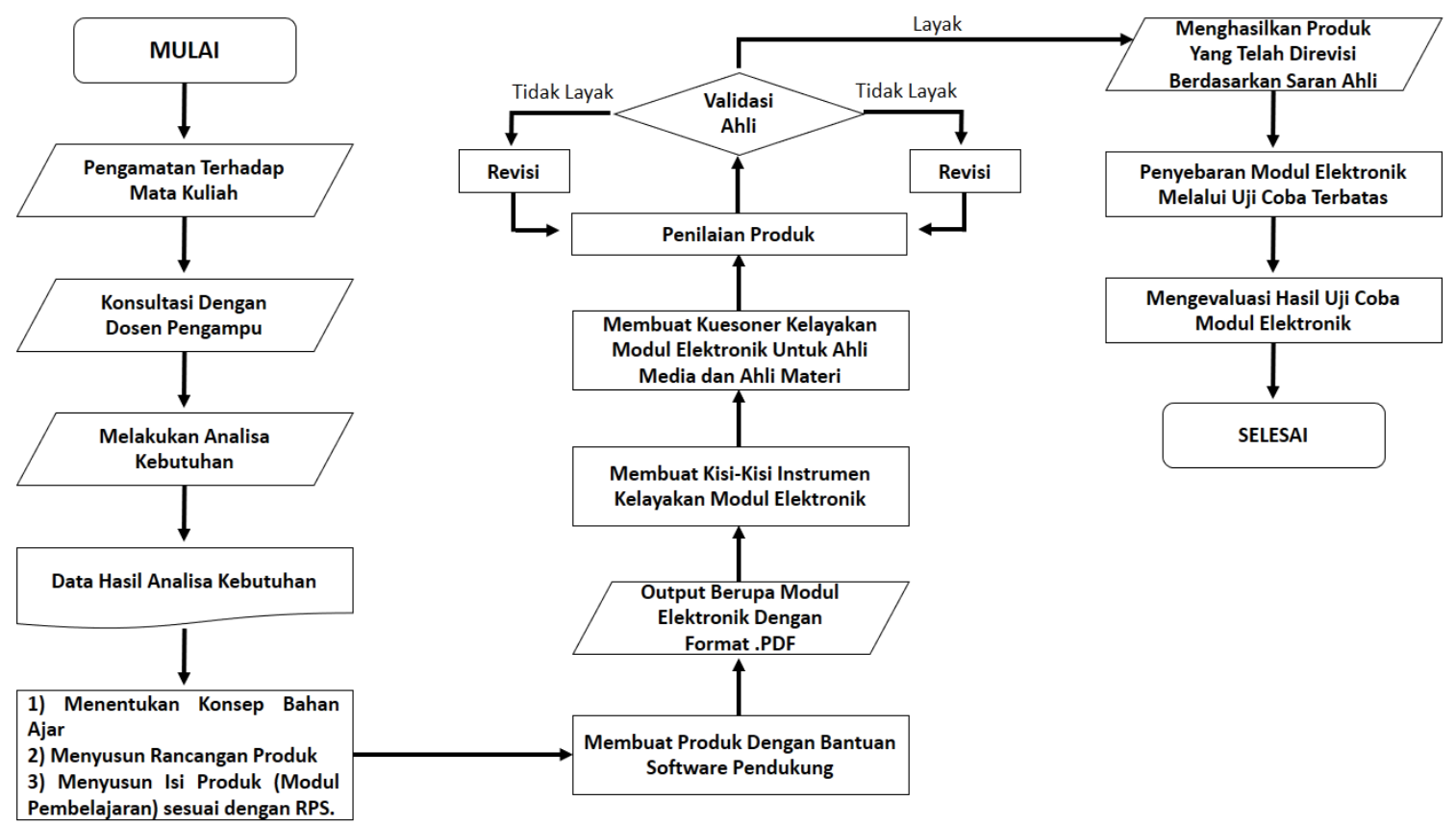

Gambar 1. Flowchart Pengembangan E-Modul Praktik Batu Beton

\section{Hasil Penelitian dan Pembahasan}

Penelitian ini menghasilkan produk berupa e-modul mata kuliah Praktik Batu Beton. E-Modul Praktik Batu Beton ini dibuat dengan menggunakan bantuan software Photoshop untuk mendesain layout modul dan software Microsoft Powerpoint untuk menyusun materi-materi yang sesuai dengan rencana perkuliahan semester mata kuliah Praktik Batu Beton. E-modul Praktik Batu Beton ini memiliki tampilan desain yang menarik dan terdapat fitur $Q R$ Code serta byperlink video pembelajaran untuk menambah pemahaman peserta didik terhadap materi pembelajaran,. Selain itu, terdapat fitur navigasi yang dapat mempermudah penggunaan modul sebagai bahan ajar. Pada bagian akhir modul terdapat tes formatif berupa lima soal pilihan ganda yang berfungsi untuk alat ukur dalam mengevaluasi tingkat pemahaman peserta didik dalam mempelajari materi yang disajikan. Menurut Hamzah (2019) evaluasi adalah proses melihat berhasil atau tidaknya produk yang telah dikembangkan. Tahap ini bertujuan untuk menilai kualitas dari produk yang dikembangkan, baik sebelum atau sesudah diimplementasikan. E-modul Praktik Batu Beton ini akan dipublikasikan melalui situs $e$-learning berupa Moodle yang terdapat di program studi Pendidikan Vokasional Konstruksi Bangunan, Universitas Negeri Jakarta, sehingga peserta didik dapat mengakses materi dengan mudah melalui gadget atau laptop yang mereka punya tanpa batasan ruang dan waktu.

Penilaian produk dilakukan dengan melakukan validasi $e$-modul Praktik Batu Beton kepada dua orang ahli media dan dua orang ahli materi. Penilaian oleh ahli media terdiri atas beberapa aspek, meliputi aspek tampilan desain, kelengkapan aplikasi, tipografi isi modul, penyajian dan kebermanfaatan. Hasil persentase penilaian yang diberikan oleh dua orang ahli media terhadap $e$-modul Praktik Batu Beton adalah $81,15 \%$. Persentase tersebut menunjukan bahwa e-modul termasuk kategori sangat layak untuk digunakan sebagai bahan ajar mata kuliah Praktik Batu Beton. 
Tabel 1. Data Hasil Validasi Ahli Media

\begin{tabular}{llll}
\hline NO & $\begin{array}{l}\text { Aspek } \\
\text { Penilaian }\end{array}$ & Persentase & Kategori \\
\hline 1 & $\begin{array}{l}\text { Tampilan } \\
\text { Desain }\end{array}$ & 84 & $\begin{array}{l}\text { Sangat } \\
\text { Layak }\end{array}$ \\
\hline 2 & $\begin{array}{l}\text { Kelengkapan } \\
\text { Aplikasi }\end{array}$ & 86 & $\begin{array}{l}\text { Sangat } \\
\text { Layak }\end{array}$ \\
\hline 3 & $\begin{array}{l}\text { Tipografi Isi } \\
\text { Modul }\end{array}$ & 80 & Layak \\
\hline 4 & Penyajian & 80 & Layak \\
\hline 5 & Kebermanfaatan & 75 & Layak \\
\hline & Rata-rata & 81,5 & Sangat \\
& & & Layak \\
\hline
\end{tabular}

Berdasarkan hasil penilaian validasi yang diberikan oleh Ahli materi menyatakan $e$-modul Praktik Batu Beton memperoleh persentase rata-rata 88\%. Persentase tersebut menunjukkan bahwa $e$-modul termasuk kategori sangat layak.

Tabel 2. Data Hasil Validasi Ahli Materi

\begin{tabular}{lccll}
\hline \multirow{2}{*}{ Modul } & \multicolumn{2}{l}{ Persentase } & $\begin{array}{l}\text { Rata-rata } \\
\text { Persentase }\end{array}$ & Kategori \\
\cline { 2 - 4 } & V1 & V2 & & \\
\hline 1 & 82 & 96 & 89 & Sangat Layak \\
\hline 2 & 77 & 98 & 88 & Sangat Layak \\
\hline 3 & 83 & 95 & 89 & Sangat Layak \\
\hline 4 & 83 & 96 & 90 & Sangat Layak \\
\hline 5 & 73 & 98 & 85 & Sangat Layak \\
\hline 6 & 75 & 98 & 87 & Sangat Layak \\
\hline 7 & 84 & 98 & 91 & Sangat Layak \\
\hline
\end{tabular}

\begin{tabular}{lccll}
\hline Modul & \multicolumn{2}{l}{ Persentase } & $\begin{array}{l}\text { Rata-rata } \\
\text { Persentase }\end{array}$ & Kategori \\
\cline { 2 - 4 } & V1 & V2 & & \\
\hline 8 & 78 & 97 & 88 & Sangat Layak \\
\hline 9 & 74 & 99 & 86 & Sangat Layak \\
\hline 10 & 70 & 99 & 85 & Sangat Layak \\
\hline 11 & 74 & 99 & 86 & Sangat Layak \\
\hline 12 & 74 & 99 & 86 & Sangat Layak \\
\hline & & & & \\
\hline
\end{tabular}

Setelah dilakukan validasi oleh ahli media dan ahli materi, langkah selanjutnya adalah melakukan uji coba untuk mengetahui efektivitas dari $e$-modul Praktik Batu Beton. Uji coba dilakukan melalui uji coba terbatas dengan memberikan soal pretest dan post-test kepada 20 mahasiswa Pendidikan Teknik Bangunan FT UNJ yang telah mengampu mata kuliah Praktik Batu Beton. Karena keterbatasan pandemi Covid 19, uji coba terbatas dilakukan melalui fitur chat WhatsApp dan Google Form. Hasil dari uji coba terbatas dapat dilihat pada Tabel 3.

Tabel 3. Data Hasil Uji Coba Terbatas

\begin{tabular}{llll}
\hline NO & $\begin{array}{l}\text { Peserta Uji } \\
\text { Coba }\end{array}$ & Pre-test & Post-test \\
\hline 1 & FAK & 64 & 92 \\
\hline 2 & AS & 64 & 100 \\
\hline 3 & FAK & 52 & 96 \\
\hline 4 & MM & 48 & 72 \\
\hline 5 & PH & 56 & 88 \\
\hline 6 & VA & 68 & 88 \\
\hline
\end{tabular}




\begin{tabular}{|c|c|c|c|}
\hline NO & $\begin{array}{l}\text { Peserta Uji } \\
\text { Coba }\end{array}$ & Pre-test & Post-test \\
\hline 7 & $\mathrm{AA}$ & 52 & 100 \\
\hline 8 & NZ & 64 & 100 \\
\hline 9 & $\mathrm{AF}$ & 68 & 100 \\
\hline 10 & SJ & 44 & 100 \\
\hline 11 & TT & 44 & 100 \\
\hline 12 & NA & 48 & 92 \\
\hline 13 & AI & 56 & 92 \\
\hline 14 & HS & 52 & 100 \\
\hline 15 & $\mathrm{MF}$ & 52 & 100 \\
\hline 16 & LM & 68 & 100 \\
\hline 17 & DIA & 24 & 92 \\
\hline 18 & DBP & 44 & 100 \\
\hline 19 & MDA & 36 & 96 \\
\hline 20 & $\mathrm{AH}$ & 32 & 100 \\
\hline & Rata-rata & 51,8 & 95,4 \\
\hline
\end{tabular}

Berdasarkan Tabel 3 dapat dilihat hasil rata-rata nilai pretest, yaitu 51,8, sedangkan hasil rata-rata nilai posttest, yaitu 95,4 . Terdapat peningkatan rata-rata nilai sebesar 45,70\%. Maka dapat disimpulkan bahwa modul elektronik Praktik Batu Beton dapat meningkatkan hasil belajar dari segi materi. Setelah melakukan uji coba terbatas, kemudian penilaian pengguna terhadap $e$ modul Praktik Batu Beton berdasarkan aspek tampilan bahan ajar, program bahan ajar, evaluasi pembelajaran dan materi pembelajaran. Penilaian pengguna dilakukan dengan menyebarkan kuesioner kepada peserta uji coba terbatas melalui Google Form. Hasil penilaian pengguna terhadap $e^{-}$ modul Praktik Batu Beton dapat dilihat pada Tabel 4.

Tabel 4. Data Penilaian Pengguna Terhadap Produk yang Dihasilkan

\begin{tabular}{llll}
\hline NO & Aspek Penilaian & Persentase & Kategori \\
\hline 1 & $\begin{array}{l}\text { Tampilan Bahan } \\
\text { Ajar }\end{array}$ & 86 & $\begin{array}{l}\text { Sangat } \\
\text { Baik }\end{array}$ \\
\hline 2 & $\begin{array}{l}\text { Program Bahan } \\
\text { Ajar }\end{array}$ & 85 & $\begin{array}{l}\text { Sangat } \\
\text { Baik }\end{array}$ \\
\hline 3 & $\begin{array}{l}\text { Evaluasi } \\
\text { Pembelajaran }\end{array}$ & 86 & $\begin{array}{l}\text { Sangat } \\
\text { Baik }\end{array}$ \\
\hline 4 & Materi & & Sangat \\
& Pembelajaran & 85 & Baik \\
& & 85 & $\begin{array}{l}\text { Sangat } \\
\text { Baik }\end{array}$ \\
\hline
\end{tabular}

Berdasarkan Tabel 4 dapat dilihat hasil persentase rata-rata penilaian pengguna terhadap e-modul Praktik Batu Beton sebesar 86\% dengan kategori "Sangat Baik" yang menunjukkan kepuasan terhadap penggunaan $e$-modul.

Hasil penelitian ini relevan dengan penelitian yang dilakukan oleh Tampubolon, Arthur, \& Daryati (2017) dengan judul "Pengembangan E-Modul Konstruksi Bangunan Pada Kompetensi Dasar Menerapkan Spesifikasi Kayu dan Karakteristik Kayu". Pada penelitian tersebut menunjukkan perbedaan peningkatan hasil belajar peserta didik yang melakukan pembelajaran menggunakan $e$ modul daripada peserta didik yang melakukan pembelajaran secara konvensional.

\section{Simpulan}

Penelitian dalam melakukan pengembangan bahan ajar berupa e-modul Praktik Batu Beton menggunakan model ADDIE yang meliputi tahap Analysis, Design, Development, Implementation, and Evaluation. Hasil penelitian menunjukkan 
bahwa $e$-modul Praktik Batu Beton termasuk kategori sangat layak dari segi materi dengan persentase $88,41 \%$ dan kategori sangat layak dari segi media dengan persentase $81,15 \%$. Hasil pelaksanaan uji coba terbatas menunjukkan peningkatan pengetahuan dan hasil belajar mahasiswa dalam $e$-modul. Sehingga dapat disimpulkan bahwa e-modul Praktik Batu Beton dapat digunakan dalam pembelajaran Pratik Batu Beton di program studi Pendidikan Teknik Bangunan, Universitas Negeri Jakarta.

\section{Daftar Pustaka}

Asmi, A. R. (2018). Pengembangan EModul Berbasis Flip Book Maker Materi. Jurnal Pendidikan Ilmu Sosial, 27, 1-10.

Hamzah, A. (2019). Metode Penelitian dan Pengembangan. Literasi Nusantara.

Prasetiyowati, Y., \& Tandoyonomanu, D. (2015). Pengembangan Modul Elektronik pada Mata Pelajaran
Animasi 3 Meningkatkan Hasil Belajar di SMK Negeri 1 Magetan. Jumal Mahasiswa Teknologi Pendidikan.

Prastowo, A. (2015). Panduan Kreatif Membuat Bahan Ajar Inovatif. PT DIVA Press.

Purwaningtyas, W. D. (2017). Pengembangan Modul Elektronik Berbasis Online Dengan Program Edmodo. Jurnal Pendidikan, 2(1), 121129.

Suwardana, H. (2018). Revolusi Industri 4.0 Berbasis Rrevolusi Mental. JATI UNIK: Jurnal Ilmiah Teknik Dan Manajemen Industri, 1(1), 102.

Tampubolon, M., Arthur, R., \& Daryati, D. (2017). Pengembangan E-Module Konstruksi Bangunan pada Kompetensi Dasar Menerapkan Speisfikasi dan Karakteristik Kayu. Jurnal Pensil, 6(2), 8. 